\title{
Correction to: An andesitic sill complex in the Southern Permian Basin: volcanogenetic model and stratigraphic implications
}

\author{
Ludwig Luthardt ${ }^{1}$ (C) . Christoph Breitkreuz ${ }^{1}$. Joerg W. Schneider ${ }^{1,2}$. Birgit Gaitzsch ${ }^{1,2}$. Judith Brink ${ }^{3}$. \\ Klaus Peter Stanek ${ }^{1}$. Ulf Linnemann ${ }^{4} \cdot$ Mandy Hofmann $^{4} \cdot$ Bodo-Carlo Ehling $^{5}$
}

Published online: 7 July 2021

(c) The Author(s) 2021

\section{Correction to: \\ International Journal of Earth Sciences \\ (2020) 109:2447-2466 \\ https://doi.org/10.1007/s00531-020-01911-y}

The article "An andesitic sill complex in the Southern Permian Basin: volcanogenetic model and stratigraphic implications" written by Ludwig Luthardt, Christoph Breitkreuz, Joerg W. Schneider, Birgit Gaitzsch, Judith Brink, Klaus Peter Stanek, Ulf Linnemann, Mandy Hofmann, Bodo-Carlo Ehling was originally published online first without open access. After publication in volume 109, issue 7, pages (2447-2466), the author decided to opt for open choice and to make the article an open access publication. Therefore, the copyright of the article has been changed to The Author(s) 2020 and the article is forthwith distributed under the terms of the Creative Commons Attribution 4.0 International License, which permits use, sharing, adaptation, distribution and reproduction in any medium or format, as long as you give appropriate credit to the original author(s) and the source, provide a link to the Creative Commons licence, and indicate if changes were

The original article can be found online at https://doi.org/10.1007/ s00531-020-01911-y.

Ludwig Luthardt

1.luthardt@gmx.de

1 Geological Institute, Technische Universität Bergakademie Freiberg, Bernhard-von-Cotta, Straße 2, 09599 Freiberg, Germany

2 Kazan Federal University, 18 Kremlevskaya Str., Kazan 420008, Russian Federation

3 Oststraße 2, 09599 Freiberg, Germany

4 Senckenberg Naturhistorische Sammlungen Dresden, GeoPlasma Lab, Königsbrücker Landstraße, 159, 01109 Dresden, Germany

5 Landesamt für Geologie und Bergwesen (LAGB), Sachsen-Anhalt, Köthener Straße 38, 06118 Halle, Germany made. The images or other third party material in this article are included in the article's Creative Commons licence, unless indicated otherwise in a credit line to the material. If material is not included in the article's Creative Commons licence and your intended use is not permitted by statutory regulation or exceeds the permitted use, you will need to obtain permission directly from the copyright holder. To view a copy of this licence, visit http://creativecommons. org/licenses/by/4.0.

The original article has been corrected.

Open Access This article is licensed under a Creative Commons Attribution 4.0 International License, which permits use, sharing, adaptation, distribution and reproduction in any medium or format, as long as you give appropriate credit to the original author(s) and the source, provide a link to the Creative Commons licence, and indicate if changes were made. The images or other third party material in this article are included in the article's Creative Commons licence, unless indicated otherwise in a credit line to the material. If material is not included in the article's Creative Commons licence and your intended use is not permitted by statutory regulation or exceeds the permitted use, you will need to obtain permission directly from the copyright holder. To view a copy of this licence, visit http://creativecommons.org/licenses/by/4.0/. 